\title{
PENYEBAB CHANGE ORDER PADA PROYEK KONSTRUKSI BANGUNAN AIR WILAYAH DKI JAKARTA
}

\author{
Ivana Ramayanti H Putri ${ }^{1}$ dan Mega Waty ${ }^{2}$ \\ ${ }^{1}$ Program Studi Sarjana Teknik Sipil, Universitas Tarumanagara, Jl. Letjen S. Parman No.1 Jakarta \\ Ivana.325179102@stu.untar.ac.id \\ ${ }^{2}$ Program Studi Sarjana Teknik Sipil, Universitas Tarumanagara, Jl. Letjen S.Parman No.1 Jakarta \\ mega@ft.ac.id
}

Masuk: 09-01-2021, revisi: 01-03-2021, diterima untuk diterbitkan: 02-03-2021

\begin{abstract}
Change orders are proposals for additional / less work where the main work does not follow the initial design or there are new proposals for new work at all (Pusat Pendidikan dan Pelatihan Sumber Daya Air dan Konstruksi, 2017). A contract or agreement has been signed before implementing the project, but changes often occur after and greatly affect the project performance. This change is also needed to be known if it occurs in a water construction project. To control change orders and contract changes, it is necessary to know the causing factors. This study aims to determine these causative factors by compiling a questionnaire distributed to workers in the water construction sector in the area of DKI Jakarta. The questionnaire results were tested for validity and reliability and Ranked by RII (Relative Importance Index) method. With the acquisition of RII above 0.51, the results found that coordination with utility systems (RII 0, 6842), is the main contributing factor to the Change Order in the construction of DKI Jakarta water buildings.
\end{abstract}

Keywords: Causes of Change Order; Water Building; RII; DKI Jakarta

\begin{abstract}
ABSTRAK
Change order adalah usulan pekerjaan tambah/kurang dimana pekerjaan utama tidak mengikuti desain awal atau terdapat usulan pekerjaan baru sama sekali(Pusat Pendidikan dan Pelatihan Sumber Daya Air dan Konstruksi, 2017). Sebelum pelaksanaan proyek, pihak yang terlibat dalam konstruksi telah menandatangani kontrak atau kesepakatan. Dalam pelaksanaannya, setelah penandatanagnan kontrak seringkali terjadi perubahan-perubahan. Perubahan sangat berpengaruh pada kinerja proyek, perubahan ini juga perlu diketahui terjadi atau tidaknya dalam proyek konstruksi air. Jika perubahan dalam proyek terjadi pada proyek konstruksi air, untuk mengendalikan perintah perubahan maupun perubahan kontrak diperlukan pengetahuan faktor penyebab terjadinya perubahan. Penelitian ini bertujuan untuk mengetahui faktor penyebab dengan penyusunan kuesioner yang disebarkan terhadap pekerja bidang konstruksi air wilayah cakupan DKI Jakarta. Setelah dilakukan uji validitas dan reliabilitas, hasil kuesioner akan diurutkan berdasar tingkat kepentingan dengan metode RII. Dengan perolehan RII diatas 0,51, hasil yang ditemukan bahwa pengkoordinasian dengan sistem utilitas (RII 0, 6842), merupakan faktor penyebab utama Change Order pada konstruksi bangunan air DKI Jakarta.
\end{abstract}

Kata kunci: Penyebab Change Order; Bangunan Air; RII; DKI Jakarta

\section{PENDAHULUAN}

Untuk menjaga pelaksanaan proyek dalam control yang baik, sebelum pelaksanaan proyek pihak yang terlibat dalam konstruksi telah menandatangani kontrak atau kesepakatan yang isinya banyak akan mempengaruhi masalah biaya, kualitas, dan waktu pengerjaan proyek.

Dalam pelaksanaan proyek konstruksi, sering terjadi perubahan-perubahan (changes). Ketidaksesuaian dengan rencana bisa disebut sebagai perubahan pekerjaan CO (change order) / Addendum Kontrak. (Hanna et al., 1999) Dengan adanya addendum kontrak, sangat mempengaruhi terjadinya perubahan harga, biaya serta waktu dalam suatu konstruksi. (Barrie dan Paulson, 1992 dalam Waty, 2013)

Disamping adanya pengaruh dari change order hasil penelitian (Waty dan Sulistio, 2020) ada pihak yang diuntungkan melalui change order. Pihak pertama yang memperoleh keuntungan dari change order adalah kontraktor, diikuti konsultan, dan dengan pihak paling tidak diuntungkan adalah pemilik. 
Cukup banyak penelitian yang telah dilakukan mengenai penyebab Change Order (CO) pada proyek konstruksi. Akan tetapi baru beberapa saja yang membahas spesifik mengenai bangunan air. Disamping itu, proyek konstruksi bangunan air yang akan dibangun Pemerintah Provinsi DKI Jakarta tahun 2020 cukup banyak seperti Waduk Brigif (Aliran Kali Krukut), Waduk Pondok Ranggon (Aliran Kali Sunter), Waduk Cimanggis (Aliran Kali Cipinang).

Berdasarkan Latar belakang tersebut, tujuan penelitian ini adalah mengantisipasi dan meminimalisir Change Order (CO) pada proyek konstruksi khususnya pembangunan Daerah Irigasi sumber daya air dimasa mendatang khususnya wilayah DKI Jakarta yang mengangkat judul "Penyebab Change Order Pada Proyek Konstruksi Bangunan Air Wilayah DKI Jakarta".

\section{Change Order}

Change Order adalah usulan pekerjaan tambah/kurang dimana pekerjaan utama tidak mengikuti desain awal atau terdapat usulan pekerjaan baru sama sekali(Pusat Pendidikan dan Pelatihan Sumber Daya Air dan Konstruksi, 2017). Terjadinya Change Order akan menyebabkan penambahan tenaga kerja disertai dengan penambahan peralatan proyek (Schaufelberger and Holm, 2017).

\section{Tipe/jenis Change Order}

Menurut Sulistio, Hendrik. Tipe Change Order secara umum dikelompokkan menjadi 5 kategori yaitu Owner acknowledged change, cardinal change, constructive change, minor change, dan consequential change.

Tabel 1. Tipe Change Order

\begin{tabular}{|c|c|c|c|c|}
\hline No & Tipe & Menurut & Tahun & Definisi \\
\hline 1. & $\begin{array}{l}\text { Owner } \\
\text { acknowledged } \\
\text { change }\end{array}$ & Civitello & 1987 & $\begin{array}{l}\text { Didefinisikan sebagai pengeluaran aktua dari pekerjaan, } \\
\text { yaitu hubungan pengeluaran untuk efek dari perubahan } \\
\text { pekerjaan diatas kontrak kerja pengaruh lainnya atau } \\
\text { pengaruh pengeluaran. }\end{array}$ \\
\hline 2. & Cardinal change & Sweet & 1985 & $\begin{array}{l}\text { Didefinisikan sebagai change order yang melebihi change } \\
\text { order normal (Perubahan diatas } 10 \% \text { ) }\end{array}$ \\
\hline 3. & $\begin{array}{l}\text { Constructive } \\
\text { change }\end{array}$ & Sweet & 1994 & $\begin{array}{l}\text { Didefinisikan sebagai perubahan konstruktif bila pengguna } \\
\text { jasa proyek atau bersifat sebagai desain professional, dan } \\
\text { konntraktor tidak merasa bahwa bekerja dibawah dokumen } \\
\text { kontrak asli. Kontraktor melakukan pekerjaan bermaksud } \\
\text { melakukan klaim tambahan kompensasi untuk melakukan } \\
\text { pekerjaan sampai batas waktu. }\end{array}$ \\
\hline 4. & Minor change & Sweet & 1994 & $\begin{array}{l}\text { Didefinisikan sebagai perubahan spesifikasi dan gambar } \\
\text { yang tidak jelas dengan skala kecil (Perubahan dibawah } \\
10 \% \text { ) }\end{array}$ \\
\hline 5. & $\begin{array}{l}\text { Consequential } \\
\text { change. }\end{array}$ & Sweet & 1994 & $\begin{array}{l}\text { Didefinisikan sebagai pekerjaan tambahan karena keperluan } \\
\text { atau tambahan biaya dengan mendadak sebagai sebuah hasil } \\
\text { langsung dari sebelum perubahan-perubahan dari proyek. } \\
\text { Consequential change mempunyai efek domino atau } \\
\text { menerus dan ini beresiko. }\end{array}$ \\
\hline
\end{tabular}

(Sumber: Sulistio, 2010) 


\section{Pengelompokan penyebab Change Order}

Berikut pengelompokan penyebab change order berdasarkan pengembangan yang dilakukan Sulistio dan Waty:

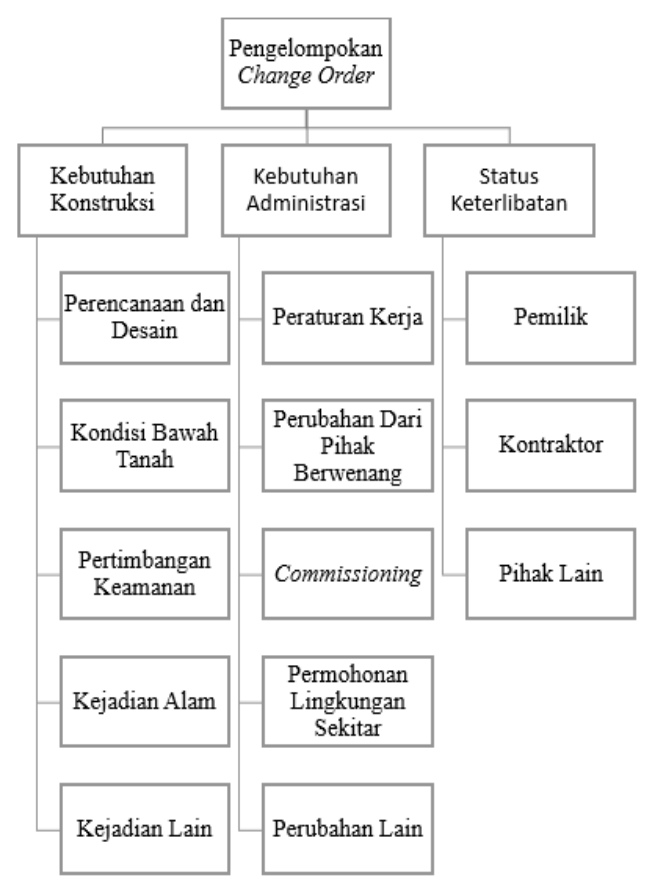

Gambar 1. Bagan pengelompokan Change Order (Sulistio dan Waty, 2008)

1. Kebutuhan konstruksi

a. Perencanaan dan desain.

- Kesalahan dalam perencanaan gambar.

- Kesalahan dalam desain.

- Kesalahan dalam pengukuran volume.

- Perencanaan yang kurang lengkap.

- Keterlambatan persetujuan desain.

- Kontrak yang kurang lengkap.

- Ketidakcocokan antara gambar design dengan keadaan lapangan.

- $\quad$ Spesifikasi desain engineering yang kurang lengkap.

- Perubahan gambar perencanaan.

- Penambahan lingkup kerja.

- Pengurangan lingkup kerja.

- Penghentian pekerjaan sementara.

- Penundaan pekerjaan sementara.

- Kontrak yang bertentangan atau kurang tegas.

- Penghentian kontrak.

- Detail kontrak yang kurang jelas.

- Buruknya koordinasi dokumen. 
- Kepadatan jadwal.

- Perintah perbaikan jadwal.

- Perintah pemunduran jadwal.

- Perintah percepatan jadwal.

- Ketidaksesuaian material dengan kondisi lapangan.

- Perubahan metode konstruksi.

- $\quad$ Perubahan lokasi proyek.

b. Kondisi bawah tanah.

- Tidak dilaksanakannya penyidikan/tes tanah.

- Penyelidikan/tes tanah lapangan yang tidak lengkap.

- Peningkatan dari penyelidikan bawah tanah.

- Kondisi bawah tanah yang berbeda terhadap hasil penyelidikan.

- Rembesan bawah tanah akibat penggalian.

- Persyaratan tambahan dari perbaikan tanah.

- Perubahan fisik yang tidak terduga dari keadaan bawah tanah atau keadaan lain.

c. Pertimbangan keamanan.

- Pertimbangan keselamatan kerja.

- Pertimbangan keamanan lapangan.

- Tambahan fasilitas keamanan.

d. Kejadian alam.

- Tanah longsor.

- Banjir.

- Penurunan tanah.

- Cuaca yang tidak umum.

e. Kejadian lain.

- Terjadinya kerusuhan, huru hara, perang, dsb..

2. Kebutuhan Administrasi

a. Peraturan kerja.

- Perubahan dari peraturan perencanaan kota.

- Perubahan berdasarkan perlindungan lingkungan.

- Perubahan dari peraturan kebakaran.

- Perubahan manajemen limbah konstruksi.

b. Perubahan dari pihak berwenang.

- Pertimbangan Politik.

- Perubahan dari pembuat keputusan.

- Perubahan penempatan awal sarana dan prasarana.

- Perubahan pasar. 
- Perbedaan pandangan antara pejabat pemerintah.

- Dominasi wewenang atasan/ pimpinan.

c. Commissioning.

- Kebutuhan tambahan untuk perawatan/ pemeliharaan.

- Menambah kebutuhan untuk penggunaan proyek terkait.

- Modifikasi desain untuk agen-agen proyek terkait.

- Kebutuhan tambahan untuk pertimbangan keselamatan mendatang.

d. Permohonan lingkungan sekitar.

- Penambahan fasilitas untuk penduduk.

- Mengurangi/ menunda bagian konstruksi sehubungan masalah lingkungan.

- Permintaan pejabat/ pemerintah setempat CSR (Corporate Social Responsibility).

e. Perubahan lain.

- Koordinasi yang terlambat disampaikan.

- Koordinasi dengan sistem utilitas.

- Keperluan dari institusi lain.

- Konflik kontrak dan perselisihan.

- Padatnya jadwal.

- Kurangnya kontrol.

- Kurangnya kerja team.

- $\quad$ Laporan akan kondisi lapangan yang kurang memadai.

- Kurang tanggapnya antisipasi terhadap keadaan tidak terduga.

- Buruknya alur informasi.

- Penundaan dalam memasuki lapangan.

- Keterlambatan dalam penyediaan perlengkapan pemilik.

- Keterlambatan respon terhadap permintaan informasi.

- Kurang lengkapnya permintaan informasi.

3. Status Keterlibatan

a. Pemilik.

- Kurang kontrol.

- Ketidakmampuan pemilik.

- Keterlambatan pemilik.

- Hal-hal yang belum ditentukan pemilik.

- Kebijakan peraturan dari pihak pemilik.Keterlambatan jadwal dari pemilik.

- Kegagalan pemilik menyediakan sites, alat, material.

- $\quad$ Penundaan pekerjaan karena permintaan pemilik. 
b. Kontraktor.

- Kurangnya pengetahuan dan pengalaman kerja.

- Terlambatnya jadwal kontraktor.

- Terlalu tingginya jumlah kerja lembur.

- Kesalahan dalam pertimbangan.

- Kurangnya kemampuan untuk membangun.

- Kekurangan tim kerja.

- Kurang memadai alat.

- Kegagalan kemampuan kontraktor.

- Perselisihan tenaga kerja.

- Keterlambatan kontraktor.

- Rendahnya keahlian pekerja.

- Penundaan pekerjaan karena keterlambatan kontraktor.

c. Pihak lain.

- Ketidakmampuan pihak ketiga.

- Campur tangan pihak ketiga.

- Kerusakan akibat pihak ketiga.

\section{METODE PENELITIAN}

Dalam penelitian ini, perumusan akan dilakukan secara deduktif, dimana dalam penarikan kesimpulan perumusan berasalkan dari kesimpulan pernyataan-pernyataan umum maupun dari pernyataan umum ke khusus. Untuk menentukan faktor-faktor yang menjadi penyebab terjadinya Change Order, penelitian ini akan menggunakan metode penyebaran kuesioner kepada pihak terkait konstruksi yang pernah terlibat dalam pembangunan konstruksi bangunan air wilayah DKI Jakarta, yang selanjutnya hasil data peroleh akan dikaji dan dianalisis.

\section{HASIL DAN PEMBAHASAN}

Kuesioner penelitian disusun berdasarkan faktor penyebab Change Order yang telah dikelompokan oleh (Finke, 1998), (Hsieh, et al., 2004), (Barrie dan Paulson, 1992), ( Iman Soeharto, 1998), ( Gilbreath, 1992), dan (Sulistio dan Waty, 2008). Peneliti melakukan pengujian penyebab Change Order yang terjadi pada proyek konstruksi bangunan air yang telah selesai pada daerah DKI Jakarta.

Data yang digunakan dalam penelitian ini merupakan hasil pengumpulan data melalui metode survey dengan melakukan penyebaran kuesioner. Jumlah pertanyaan dalam kuesioner ini berjumlah 57 pertanyaan, Dimana penyebaran kuesioner pada penelitian ini dibagikan kepada lima wilayah DKI Jakarta dengan Responden terkumpul atas nama Instansi Suku Dinas Sumber Daya Air DKI Jakarta.

Hasil validitas kuesioner ditampilkan pada Tabel 2 sampai dengan 4. Dari hasil perhitungan dengan program IBM SPSS 25, hasil uji validitas seluruh bariabel valid dengan nilai signifikansi 0,05 dan berasal dari jumlah keseluruhan 38 responden. 
Tabel 2. Hasil validitas kuesioner kebutuhan konstruksi

\begin{tabular}{|c|c|c|c|c|c|}
\hline No & Variabel & Faktor penyebab Change Order & Rtabel 5\% & R hitung & Keterangan \\
\hline 1 & \multirow{15}{*}{$\begin{array}{l}\text { Perencanaan dan } \\
\text { Desain }\end{array}$} & Kesalahan dalam perencanaan & 0,320 & 0,758 & Data Valid \\
\hline 2 & & Kesalahan dan kelalaian dalam penentuan estimasi & 0,320 & 0,722 & Data Valid \\
\hline 3 & & Kontrak yang kurang lengkap & 0,320 & 0,701 & Data Valid \\
\hline 4 & & $\begin{array}{l}\text { Ketidakcocokan antara gambar design dengan keadaan } \\
\text { lapangan }\end{array}$ & 0,320 & 0,687 & Data Valid \\
\hline 5 & & Spesifikasi desain engineering yang kurang lengkap & 0,320 & 0,798 & Data Valid \\
\hline 6 & & Perubahan perencanaan & 0,320 & 0,676 & Data Valid \\
\hline 7 & & Penambahan lingkup kerja & 0,320 & 0,769 & Data Valid \\
\hline 8 & & Pengurangan lingkup kerja & 0,320 & 0,738 & Data Valid \\
\hline 9 & & Penghentian pekerjaan sementara & 0,320 & 0,677 & Data Valid \\
\hline 10 & & Ketentuan kontrak yang bertentangan atau kurang tegas & 0,320 & 0,763 & Data Valid \\
\hline 11 & & Kepadatan jadwal & 0,320 & 0,791 & Data Valid \\
\hline 12 & & Perintah perbaikan jadwal & 0,320 & 0,803 & Data Valid \\
\hline 13 & & Perintah pemunduran jadwal & 0,320 & 0,690 & Data Valid \\
\hline 14 & & Perintah percepatan jadwal & 0,320 & 0,861 & Data Valid \\
\hline 15 & & $\begin{array}{l}\text { Keterlambatan dalam persetujuan perlengkapan gambar atau } \\
\text { perlengkapan pemilik }\end{array}$ & 0,320 & 0,798 & Data Valid \\
\hline 1 & \multirow{7}{*}{$\begin{array}{l}\text { Kondisi Bawah } \\
\text { Tanah }\end{array}$} & Tidak dilaksanakannya penyidikan/tes tanah & 0,320 & 0,822 & Data Valid \\
\hline 2 & & Penyelidikan/tes tanah lapangan yang tidak lengkap & 0,320 & 0,819 & Data Valid \\
\hline 3 & & Peningkatan dari penyelidikan bawah tanah & 0,320 & 0,890 & Data Valid \\
\hline 4 & & $\begin{array}{l}\text { Kondisi bawah tanah yang berbeda terhadap hasil } \\
\text { penyelidikan }\end{array}$ & 0,320 & 0,915 & Data Valid \\
\hline 5 & & Rembesan bawah tanah akibat penggalian & 0,320 & 0,862 & Data Valid \\
\hline 6 & & Persyaratan tambahan dari perbaikan tanah & 0,320 & 0,917 & Data Valid \\
\hline 7 & & $\begin{array}{l}\text { Perubahan fisik yang tidak terduga dari keadaan bawah } \\
\text { tanah atau keadaan lain. }\end{array}$ & 0,320 & 0,772 & Data Valid \\
\hline 1 & \multirow{3}{*}{ Keselamatan Kerja } & Pertimbangan keselamatan kerja & 0,320 & 0,980 & Data Valid \\
\hline 2 & & Pertimbangan keamanan lapangan & 0,320 & 0,974 & Data Valid \\
\hline 3 & & Tambahan fasilitas keamanan & 0,320 & 0,884 & Data Valid \\
\hline 1 & \multirow{4}{*}{ Faktor Alam } & Tanah longsor & 0,320 & 0,874 & Data Valid \\
\hline 2 & & Banjir & 0,320 & 0,878 & Data Valid \\
\hline 3 & & Penurunan tanah & 0,320 & 0,948 & Data Valid \\
\hline 4 & & Cuaca yang tidak umum & 0,320 & 0,866 & Data Valid \\
\hline 1 & Faktor Lain & Terjadinya kerusuhan, huru hara, perang, dsb. & 0,320 & 1,000 & Data Valid \\
\hline
\end{tabular}


Tabel 3. Hasil validitas kuesioner kebutuhan administrasi

\begin{tabular}{|c|c|c|c|c|c|}
\hline No & Variabel & Faktor penyebab Change Order & Rtabel 5\% & R hitung & Keterangan \\
\hline 1 & \multirow{2}{*}{ Peraturan Kerja } & Perubahan dari peraturan perencanaan kota & 0,320 & 0,951 & Data Valid \\
\hline 2 & & Perubahan berdasarkan perlindungan lingkungan & 0,320 & 0,958 & Data Valid \\
\hline 1 & \multirow{3}{*}{$\begin{array}{l}\text { Perubahan dari } \\
\text { Pihak Berwenang }\end{array}$} & Pertimbangan Politik & 0,320 & 0,915 & Data Valid \\
\hline 2 & & Perubahan penempatan awal sarana dan prasarana & 0,320 & 0,895 & Data Valid \\
\hline 3 & & Dominasi wewenang atasan/ pimpinan & 0,320 & 0,767 & Data Valid \\
\hline 1 & \multirow{4}{*}{ Commissioning } & Kebutuhan tambahan untuk perawatan/pemeliharaan & 0,320 & 0,900 & Data Valid \\
\hline 2 & & $\begin{array}{l}\text { Menambah kebutuhan untuk penggunaan proyek } \\
\text { terkait }\end{array}$ & 0,320 & 0,850 & Data Valid \\
\hline 3 & & Modifikasi desain untuk agen-agen proyek terkait & 0,320 & 0,816 & Data Valid \\
\hline 4 & & $\begin{array}{l}\text { Kebutuhan tambahan untuk pertimbangan keselamatan } \\
\text { mendatang }\end{array}$ & 0,320 & 0,946 & Data Valid \\
\hline 1 & \multirow{5}{*}{$\begin{array}{l}\text { Permohonan } \\
\text { Lingkungan Sekitar }\end{array}$} & Penambahan fasilitas untuk penduduk & 0,320 & 0,785 & Data Valid \\
\hline 2 & & $\begin{array}{l}\text { Mengurangi/ menunda bagian konstruksi sehubungan } \\
\text { masalah lingkungan }\end{array}$ & 0,320 & 0,767 & Data Valid \\
\hline 3 & & $\begin{array}{l}\text { Permintaan pejabat/ pemerintah setempat CSR } \\
\text { (Corporate Social Responsibility) }\end{array}$ & 0,320 & 0,839 & Data Valid \\
\hline 4 & & Koordinasi dengan sistem utilitas & 0,320 & 0,859 & Data Valid \\
\hline 5 & & Keperluan dari institusi lain & 0,320 & 0,788 & Data Valid \\
\hline
\end{tabular}

Tabel 4. Hasil validitas kuesioner status keterlibatan

\begin{tabular}{|c|c|c|c|c|c|}
\hline No & Variabel & Faktor penyebab Change Order & Rtabel 5\% & $\mathrm{R}$ hitung & Keterangan \\
\hline 1 & & Kurang control & 0,320 & 0,944 & Data Valid \\
\hline 2 & Pemilik & Ketidakmampuan pemilik & 0,320 & 0,895 & Data Valid \\
\hline 3 & & Keterlambatan pemilik & 0,320 & 0,923 & Data Valid \\
\hline 1 & & Kurangnya pengetahuan dan pengalaman kerja & 0,320 & 0,657 & Data Valid \\
\hline 2 & & Terlambatnya jadwal kontraktor & 0,320 & 0,879 & Data Valid \\
\hline 3 & & Terlalu tingginya jumlah kerja lembur & 0,320 & 0,557 & Data Valid \\
\hline 4 & Kontraktor & Kekurangan tim kerja & 0,320 & 0,819 & Data Valid \\
\hline 5 & & Kurang memadai alat & 0,320 & 0,881 & Data Valid \\
\hline 6 & & Perselisihan tenaga kerja & 0,320 & 0,686 & Data Valid \\
\hline 7 & & Keterlambatan kontraktor & 0,320 & 0,834 & Data Valid \\
\hline 1 & & Ketidakmampuan pihak ketiga & 0,320 & 0,896 & Data Valid \\
\hline 2 & Pihak Lain & Campur tangan pihak ketiga & 0,320 & 0,908 & Data Valid \\
\hline 3 & & Kerusakan akibat pihak ketiga & 0,320 & 0,926 & Data Valid \\
\hline
\end{tabular}


Tabel 5. Hasil reliabilitas kuesioner

\begin{tabular}{|c|c|c|c|}
\hline No & Variabel & $\begin{array}{c}\text { Cronbach's } \\
\text { Alpha }\end{array}$ & $\begin{array}{l}\text { Nof } \\
\text { Items }\end{array}$ \\
\hline \multicolumn{4}{|c|}{ A. Kebutuhan Konstruksi } \\
\hline 1 & Perencanaan dan Design & 0,944 & 15 \\
\hline 2 & Kondisi Bawah Tanah & 0,940 & 7 \\
\hline 3 & Keselamatan Kerja & 0,941 & 3 \\
\hline 4 & Faktor Alam & 0,913 & 4 \\
\hline 5 & Faktor Lain & 1,000 & 2 \\
\hline \multicolumn{4}{|c|}{ B. Kebutuhan Administrasi } \\
\hline 1 & Peraturan Kerja & 0,901 & 2 \\
\hline 2 & Perubahan dari Pihak Berwenang & 0,811 & 3 \\
\hline 3 & Commissioning & 0,899 & 4 \\
\hline 4 & Permohonan Lingkungan Sekitar & 0,867 & 5 \\
\hline \multicolumn{4}{|c|}{ C. Status Keterlibatan } \\
\hline 1 & Pemilik & 0,910 & 3 \\
\hline 2 & Kontraktor & 0,877 & 7 \\
\hline 3 & Pihak Lain & 0,896 & 3 \\
\hline
\end{tabular}

Dari hasil proses perhitungan pengujian reliabilitas dengan bantuan program IBM SPSS 25, seluruh variable lolos terhadap uji reliabilitas ini dimana hasil peroleh Cronbach's Alpha melampaui batas syarat yaitu 0,7 jika Cronbach's Alpha koefisien yang setiap item lebih besar dari ambang nilai 0,7 direkomendasikan oleh (Nunally (1978) dan Hair et al.(2006) dalam Waty dan Sulistio 2020)., sehingga 57 pertanyaan yang ada lulus dalam pengujian reliabilitas.

Berdasarkan perolehan pengolahan data dengan metode RII, diperoleh:

Tabel 6. Hasil olah data RII (Relative Importance Index) secara umum keseluruhan

\begin{tabular}{|c|c|c|c|c|c|}
\hline No & Variabel & & Faktor Penyebab Change Order & RII & Rank \\
\hline \multicolumn{6}{|c|}{ A. Kebutuhan Konstruksi } \\
\hline 1 & Perencanaan dan Desain & $\mathrm{X} 1.1$ & Kesalahan dalam perencanaan & 0,4430 & 32 \\
\hline 2 & & $\mathrm{X} 1.2$ & Kesalahan dan kelalaian dalam penentuan estimasi & 0,4079 & 37 \\
\hline 3 & & $\mathrm{X} 1.3$ & Kontrak yang kurang lengkap & 0,3816 & 46 \\
\hline 4 & & $\mathrm{X} 1.4$ & Ketidakcocokan antara gambar design dengan keadaan lapangan & 0,4825 & 23 \\
\hline 5 & & $\mathrm{X} 1.5$ & Spesifikasi desain engineering yang kurang lengkap & 0,4079 & 37 \\
\hline 6 & & $\mathrm{X} 1.6$ & Perubahan perencanaan & 0,5132 & 15 \\
\hline 7 & & $\mathrm{X} 1.7$ & Penambahan lingkup kerja & 0,5263 & 13 \\
\hline 8 & & $\mathrm{X} 1.8$ & Pengurangan lingkup kerja & 0,4685 & 27 \\
\hline 9 & & $\mathrm{X} 1.9$ & Penghentian pekerjaan sementara & 0,3684 & 49 \\
\hline 10 & & $\mathrm{X} 1.10$ & Ketentuan kontrak yang bertentangan atau kurang tegas & 0,3816 & 46 \\
\hline 11 & & $\mathrm{X} 1.11$ & Kepadatan jadwal & 0,4693 & 26 \\
\hline 12 & & $\mathrm{X} 1.12$ & Perintah perbaikan jadwal & 0,4912 & 19 \\
\hline 13 & & $\mathrm{X} 1.13$ & Perintah pemunduran jadwal & 0,4474 & 31 \\
\hline 14 & & $\mathrm{X} 1.14$ & Perintah percepatan jadwal & 0,5351 & 10 \\
\hline 15 & & $\mathrm{X} 1.15$ & Keterlambatan dalam persetujuan perlengkapan gambar atau perlengkapan pemilik & 0,4956 & 18 \\
\hline
\end{tabular}


Tabel 6. Hasil olah data RII (Relative Importance Index) secara umum keseluruhan (lanjutan)

\begin{tabular}{|c|c|c|c|c|c|}
\hline No & Variabel & & Faktor Penyebab Change Order & RII & Rank \\
\hline 1 & \multirow{7}{*}{$\begin{array}{c}\text { Kondisi Bawah } \\
\text { Tanah }\end{array}$} & $\mathrm{X} 2.1$ & Tidak dilaksanakannya penyidikan/tes tanah & 0,3553 & 55 \\
\hline 2 & & $\mathrm{X} 2.2$ & Penyelidikan/tes tanah lapangan yang tidak lengkap & 0,3640 & 53 \\
\hline 3 & & $\mathrm{X} 2.3$ & Peningkatan dari penyelidikan bawah tanah & 0,4211 & 35 \\
\hline 4 & & $\mathrm{X} 2.4$ & Kondisi bawah tanah yang berbeda terhadap hasil penyelidikan & 0,4605 & 29 \\
\hline 5 & & $\mathrm{X} 2.5$ & Rembesan bawah tanah akibat penggalian & 0,4561 & 30 \\
\hline 6 & & $\mathrm{X} 2.6$ & Persyaratan tambahan dari perbaikan tanah & 0,4430 & 32 \\
\hline 7 & & $\mathrm{X} 2.7$ & Perubahan fisik yang tidak terduga dari keadaan bawah tanah atau keadaan lain. & 0,4912 & 19 \\
\hline 1 & \multirow[t]{3}{*}{ Keselamatan Kerja } & $\mathrm{X} 3.1$ & Pertimbangan keselamatan kerja & 0,5965 & 3 \\
\hline 2 & & $\mathrm{X} 3.2$ & Pertimbangan keamanan lapangan & 0,5965 & 3 \\
\hline 3 & & $\mathrm{X} 3.3$ & Tambahan fasilitas keamanan & 0,6053 & 2 \\
\hline 1 & \multirow[t]{4}{*}{ Faktor Alam } & $\mathrm{X} 4.1$ & Tanah longsor & 0,4211 & 35 \\
\hline 2 & & $\mathrm{X} 4.2$ & Banjir & 0,5307 & 12 \\
\hline 3 & & $\mathrm{X} 4.3$ & Penurunan tanah & 0,4912 & 19 \\
\hline 4 & & $\mathrm{X} 4.4$ & Cuaca yang tidak umum & 0,5570 & 8 \\
\hline 1 & Faktor Lain & $\mathrm{X} 5$ & Terjadinya kerusuhan, huru hara, perang, dsb. & 0,3509 & 56 \\
\hline & & & B. Kebutuhan Administrasi & & \\
\hline 1 & \multirow[t]{2}{*}{ Peraturan Kerja } & X6.1 & Perubahan dari peraturan perencanaan kota & 0,3684 & 49 \\
\hline 2 & & $\mathrm{X} 6.2$ & Perubahan berdasarkan perlindungan lingkungan & 0,3991 & 41 \\
\hline 1 & \multirow{3}{*}{$\begin{array}{c}\text { Perubahan dari } \\
\text { Pihak Berwenang }\end{array}$} & X7.1 & Pertimbangan Politik & 0,3684 & 49 \\
\hline 2 & & $\mathrm{X} 7.2$ & Perubahan penempatan awal sarana dan prasarana & 0,3816 & 46 \\
\hline 3 & & $\mathrm{X} 7.3$ & Dominasi wewenang atasan/ pimpinan & 0,4079 & 37 \\
\hline 1 & \multirow[t]{4}{*}{ Commissioning } & $\mathrm{X} 8.1$ & Kebutuhan tambahan untuk perawatan/pemeliharaan & 0,5658 & 7 \\
\hline 2 & & $\mathrm{X} 8.2$ & Menambah kebutuhan untuk penggunaan proyek terkait & 0,5526 & 9 \\
\hline 3 & & $\mathrm{X} 8.3$ & Modifikasi desain untuk agen-agen proyek terkait & 0,5088 & 16 \\
\hline 4 & & $\mathrm{X} 8.4$ & Kebutuhan tambahan untuk pertimbangan keselamatan mendatang & 0,5702 & 5 \\
\hline 1 & \multirow{5}{*}{$\begin{array}{c}\text { Permohonan } \\
\text { Lingkungan } \\
\text { Sekitar }\end{array}$} & $\mathrm{X} 9.1$ & Penambahan fasilitas untuk penduduk & 0,5088 & 16 \\
\hline 2 & & X9.2 & Mengurangi/ menunda bagian konstruksi sehubungan masalah lingkungan & 0,5219 & 14 \\
\hline 3 & & X9.3 & Permintaan pejabat/ pemerintah setempat CSR (Corporate Social Responsibility) & 0,5351 & 10 \\
\hline 4 & & X9.4 & Koordinasi dengan sistem utilitas & 0,6842 & 1 \\
\hline 5 & & X9.5 & Keperluan dari institusi lain & 0,5702 & 5 \\
\hline \multicolumn{6}{|c|}{ C. Status Keterlibatan } \\
\hline 1 & \multirow[t]{3}{*}{ Pemilik } & $\mathrm{X} 10.1$ & Kurang control & 0,3640 & 53 \\
\hline 2 & & $\mathrm{X} 10.2$ & Ketidakmampuan pemilik & 0,3465 & 57 \\
\hline 3 & & $\mathrm{X} 10.3$ & Keterlambatan pemilik & 0,3904 & 43 \\
\hline
\end{tabular}


Tabel 6. Hasil olah data RII (Relative Importance Index) secara umum keseluruhan (lanjutan)

\begin{tabular}{|c|c|c|c|c|c|}
\hline No & Variab & & Faktor Penyebab Change Order & RII & Rank \\
\hline 1 & Kontraktor & $\mathrm{X} 11.1$ & Kurangnya pengetahuan dan pengalaman kerja & 0,3904 & 43 \\
\hline 2 & & $\mathrm{X} 11.2$ & Terlambatnya jadwal kontraktor & 0,4868 & 22 \\
\hline 3 & & $\mathrm{X} 11.3$ & Terlalu tingginya jumlah kerja lembur & 0,4630 & 28 \\
\hline 4 & & $\mathrm{X} 11.4$ & Kekurangan tim kerja & 0,4781 & 24 \\
\hline 5 & & $\mathrm{X} 11.5$ & Kurang memadai alat & 0,4342 & 34 \\
\hline 6 & & X11.6 & Perselisihan tenaga kerja & 0,3684 & 49 \\
\hline 7 & & $\mathrm{X} 11.7$ & Keterlambatan kontraktor & 0,4737 & 25 \\
\hline 1 & Pihak Lain & $\mathrm{X} 12.1$ & Ketidakmampuan pihak ketiga & 0,3991 & 41 \\
\hline 2 & & $\mathrm{X} 12.2$ & Campur tangan pihak ketiga & 0,4079 & 37 \\
\hline 3 & & $\mathrm{X} 12.3$ & Kerusakan akibat pihak ketiga & 0,3904 & 43 \\
\hline
\end{tabular}

Jika keseluruhan responden memberikan tanggapan dengan skala 1 pada faktor yang ditanyakan perolehan nilai RII $=-1$, sedangkan jika seluruh responden memberikan tanggapan pada skala 6 maka akan diperoleh nilai RII $=1$. Dengan demikian nilai indeks kepentingan relatif yang diperoleh memiliki arti bahwa nilai kepentingan relatif (RII) -1 sampai dengan -0,5 menunjukkan faktor tidak menjadi penyebab terjadinya Change Order, tingkat kepentingan relatif RII > -0,5 sampai dengan 0 memiliki arti tidak menentukan, RII > 0 dan kurang dari 0,5 berarti memberikan pengaruh terhadap Change Order nilai RII lebih dari 0,51 sampai dengan 1 berarti faktor tersebut merupakan Penyebab terjadinya Change Order.

\section{KESIMPULAN DAN SARAN}

Dari hasil perhitungan dan analisis, dapat ditarik kesimpulan :

1. Faktor penyebab change order berdasarkan peringkat adalah: Yang pertama Koordinasi dengan sistem utilitas (RII 0, 6842), kemudian Tambahan Fasilitas Keamanan dengan perolehan (RII 0,6053), lalu Pertimbangan Keselamatan Kerja (RII 0,5965) dan yang terakhir Pertimbangan Keamanan Lapangan (RII 0,5965)

2. Faktor utama yang mempengaruhi change order berdasarkan kategori adalah:

a. Perencanaan dan Desain:

- Perintah percepatan jadwal (RII: 0, 5351).

b. Kondisi Bawah Tanah

- Perubahan fisik yang tidak terduga dari keadaan bawah tanah atau keadaan (RII 0, 4912).

c. Keselamatan Kerja

- Tambahan fasilitas keamanan keamanan (RII 0, 6053).

d. Faktor Alam

- Cuaca yang tidak umum (RII 0, 5570).

e. Faktor Lain

- Terjadinya kerusuhan, huru hara, perang, dsb. (RII 0, 3465).

f. Peraturan Kerja

- Perubahan berdasarkan perlindungan lingkungan (RII 0, 3991).

g. Perubahan dari Pihak Berwenang

- Dominasi wewenang atasan/ pimpinan (RII 0, 4079).

h. Commissioning

- Kebutuhan tambahan untuk pertimbangan keselamatan mendatang (RII 0, 5702)

i. Permohonan Lingkungan Sekitar

- Koordinasi dengan sistem utilitas (RII 0, 6842).

j. $\quad$ Pemilik

- Ketidakmampuan pemilik dengan perolehan (RII 0, 3991).

k. Kontraktor

- Terlambatnya jadwal kontraktor (RII 0, 4868).

1. Pihak Lain

- Campur tangan pihak ketiga (RII 0, 4079). 
Saran:

1. Diperlukan koordinasi antara stakeholder sistem utilitas, tambahan fasilitas keamanan, pertimbangan keselamatan kerja, pertimbangan keamanan lapangan untuk mengendalikan change order.

2. Perlu analisis lebih lanjut kepada peneliti berikutnya terhadap topik terkait change order khususnya pada konstruksi bangunan air.

\section{DAFTAR PUSTAKA}

Barrie, D. S. and Paulson, B. C. Professional construction management: including CM, design-construct, and general contracting. McGraw-Hill. (1992)

Finke, M. R. "A Better Way To Estimate And Mitigate Disruption," Journal of Construction Engineering and Management, 124, (1998): 490-497.

Gilbreath, R. D. Managing Construction Contracts: Operational Controls for Commercial Risks. 2nd edn. New York: Wiley. 1992

Hanna, A. S. et al. "Impact Of Change Orders On Labor Efficiency For Mechanical Construction," Journal Of Construction Engineering And Management, 125, (1999) :176-184.

Hsieh, T. Y., Lu, S. T. and $\mathrm{Wu}, \mathrm{C}$. H. "Statistical analysis of causes for change orders in metropolitan public works," International Journal of Project Management, 22(8), (2004) : 679-686.

MT, Sulistio, et al. "Analysis and Evaluation Change Order in Flexible Pavement (Case Study: Road Projects in East Kalimantan)." Analysis and Evaluation Change Order in Flexible Pavement (Case Study: Road Projects in East Kalimantan) (2008): 1-23.

Pusat Pendidikan dan Pelatihan Sumber Daya Air dan Konstruksi. "Modul Pengendalian Pengawasan Pada Persiapan Pelaksanaan Pekerjaan Konstruksi- Pelatihan Pengendalian Pengawasan Pekerjaan Konstruksi”. 2017.

Schaufelberger, J. E. ; and Holm, L. "Management of Construction Projects: A Constructor's Perspective”. 2nd edn. Routledge. 2017.

Soeharto, I. “Manajemen Proyek (Dari Konseptual Sampai Operasional”. 2nd edn. Jakarta: Erlangga. 1999

Sulistio, H. "Model Pengaruh Pengelolaan Change Order Terhadap Kehilangan Produktivitas Dan Performa Proyek Konstruksi Jalan" Universitas Diponogoro. 2010.

Waty, M. “Analisa Change Order pada Proyek Perkerasaan Jalan”. Bandung: STEMBI-Bandung Business School. 2013.

Waty, Mega, and Hendrik Sulistio. "Identifikasi Risiko Lanjutan Terhadap Sumber dan Penyebab Material Waste Proyek Konstruksi Jalan." Media Komunikasi Teknik Sipil 26.1 (2020): 104-117.

Waty, Mega, and Hendrik Sulistio. "Perhitungan Change Order Proyek Jalan Di Banten." Jurnal Muara Sains, Teknologi, Kedokteran dan Ilmu Kesehatan 4.2 (2020): 211-220. 